\title{
The Caudal-Related Homeodomain Proteins Upregulate catalase Expression in Drosophila Hindgut and Human Colorectal Carcinoma Cells
}

\author{
Jae-Hong Park ${ }^{1^{\dagger}}$, So-Young Park ${ }^{{ }^{\dagger}}$, Dong-Ho Lee ${ }^{1}$, Young-Shin $\mathrm{Kim}^{2}$ and Mi-Ae Yoo* \\ ${ }^{1}$ Department of Molecular Biology and ${ }^{2}$ Research Institute of Genetic Engineering, Pusan National University, Busan 609-735, Korea
}

Received December 7, 2010 / Accepted January 4, 2011

\begin{abstract}
Caudal-related homeodomain proteins play critical roles in intestine development and maintenance from Drosophila to humans. The loss or reduction of CDX1 and CDX2 are known to be associated with colon cancers. It has been well known that colorectal carcinogenesis is associated with serious oxidative stress and that catalase is decreased in colon carcinomas. However, the underlying molecular mechanisms remain elusive. Here, we report that Caudal-related homeodomain proteins positively regulate catalase expression in both Drosophila and humans. We found that Drosophila caudal heterozygotes have a decreased catalase expression and increased ROS generation in the hindgut, and that the overexpression of Caudal increases catalase promoter activity and catalase mRNA levels. We also found that CDX1 and CDX2 up-regulate catalase promoter activity and protein levels in HCT116 cells - human colorectal carcinoma cell lines. The level of catalase protein in several colorectal carcinoma cell lines was associated with CDX1 expression. These results suggest that CDX1 and CDX2 may be involved in intestinal homeostasis and tumorigenesis via regulation of catalase expression.
\end{abstract}

Key words : Drosophila caudal, CDX1, CDX2, catalase, colorectal carcinoma

\section{Introduction}

Homeodomain proteins are essential in the control of normal embryonic development [18]. Cdx1 and Cdx2 are members of the caudal-related homeobox gene family based on their sequence homology to the caudal gene of Drosophila [25]. The Caudal-related homeodomain proteins play critical roles for intestine development and maintenance from Drosophila to human $[8,20]$. Drosophila Caudal is required for definition of the anteroposterior axis during early embryogenesis [26] and hindgut development [41]. In vertebrates, Cdx1 is expressed in the crypts where epithelial cells are proliferating, whereas $\mathrm{Cdx} 2$ is mainly expressed in the villi lined by differentiated cells [33]. These homeobox genes participate in the control of intestinal homeostasis by regulating the equilibrium between proliferation and differentiation during the constant renewal of the gut epithelium. Alternated expression of homeodomain proteins is associated with the initiation and progression of cancer [23]. $\mathrm{Cdx} 1$ and $\mathrm{Cdx} 2$ expression are preferentially silenced or reduced with the progression to colon cancer in human $[3,40]$.

\footnotetext{
*Corresponding author

Tel : +82-51-510-2278, Fax : +82-51-513-9258

E-mail : mayoo@pusan.ac.kr

†Present address: Department of Molecular Cellular Biochemistry, College of Medicine, Ohio State University, OH 43210, USA
}

Heterozygous $\mathrm{Cdx} 2$ knockout mice have been known to develop colonic tumors [6]. These facts indicate that the loss or reduction of $\mathrm{Cdx} 1$ and $\mathrm{Cdx} 2$ are associated with colorectal carcinogenesis. However, the underlying molecular mechanisms remain elusive.

Colorectal carcinogenesis has been well known to be associated with serious oxidative stress [4]. Recently, it was reported that gradual advancement of oxidative-antioxidative disorders is followed by progression of colorectal cancer [34]. In considering a critical function for oxidative stress in progression of colorectal cancers, regulation of the activities of $\mathrm{H}_{2} \mathrm{O}_{2}$ metabolizing enzymes, such as superoxide dimutase (SOD), catalase and glutathione peroxidase (GPx) are likely to be required [34]. Among the anti-oxidants, catalase is a heme-containing peroxisomal enzyme and protects the $\mathrm{H}_{2} \mathrm{O}_{2}$ generated in normal human tissues [27]. Catalase has been well known to be decreased in colon carcinomas [21]. Although several studies have demonstrated tissue-specific expression of the catalase gene in mammals $[24,36]$ and constitutively elevated catalase expression at the transcriptional level by both SP1 and CCAAT-recognizing factors [28], the mechanisms of catalase regulation are little known. In previous study, we found that Drosophila catalase gene expression is regulated by DREF [29], which is also a key regulator of Drosophila caudal gene expression [7]. Therefore, we thought that Caudal-related transcription fac- 
tors may modulate catalase gene expression. We did BLAST search and found that, interestingly, several consensus DNA-binding sites for Caudal-related homeodomain protein are located in the 5'-flanking regions of Drosophila and human catalase indicating some possible links between catalase expression and Caudal-related homeodomain proteins. In the present study, we have investigated the role of Caudal-related homeodomain proteins in regulation of the catalase gene in Drosophila hindgut and human colorectal carcinoma cell lines. Our results suggest that Caudal-related homeodomain proteins positively regulate the expression of catalase in both Drosophila and human.

\section{Materials and Methods}

\section{Fly stock}

Fly stocks were maintained at $25^{\circ} \mathrm{C}$ on standard food. The catalase-lacZ [29] and UAS-cad [15] transgenic flies described previously were used. The cad $/$ Gla and hs-GAL4 strain were kindly supplied by the Bloomington Stock Center. Oregon- $R$ was used as wild type. The cad $A$,cata-

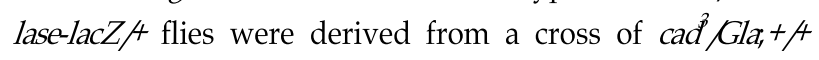
male flies to female flies carrying homozygous catalaselac $Z$ on the third chromosome, and $+A$,catalase-lac $Z / A$ flies were derived from a cross of the Oregon- $R$ males to homozygous catalase-lac $Z$ female flies. For ectopic expression of Caudal using the GAL4-UAS system, the UAS-cad/4,hs-GALA/4 flies were derived from a cross of the males carrying homozygous UAS-cad on the second chromosome to females carrying homozygous $h s-G A L 4$ on the third chromosome, and the $+A, h s-G A L A 4+$ flies were derived from a cross of the Oregan- $R$ males to females carrying homozygous $h s-G A L A$ on the third chromosome. The progeny third instar larvae were heat-shocked at $37^{\circ} \mathrm{C}$ for $45 \mathrm{~min}$ and then returned to $25^{\circ} \mathrm{C}$.

\section{$X$-Gal staining}

The tissues were dissected and fixed for $15 \mathrm{~min}$ in PBS containing $1 \%$ glutaraldehyde, washed in PBS and immersed in 0.2\% 5-bromo-4-chloro-3-indolyl- $\beta$-D-galactopyranoside (X-gal) in staining buffer containing $6.1 \mathrm{mM}$ $\mathrm{K}_{4} \mathrm{Fe}(\mathrm{CN})_{6}, 6.1 \mathrm{mM} \mathrm{K} 3 \mathrm{Fe}(\mathrm{CN})_{6}, 1 \mathrm{mM} \mathrm{MgCl}, 150 \mathrm{mM} \mathrm{NaCl}$, $10 \mathrm{mM} \mathrm{Na}_{2} \mathrm{HPO}_{4}$ and $10 \mathrm{mM} \mathrm{NaH} \mathrm{PO}_{4}$. Incubation was in the dark at $37^{\circ} \mathrm{C}$.

\section{Plasmid construction}

To construct phCat-Luc, the upstream region of human
Catalase gene ( -906 to +18 with respect to the transcription initiation site) was amplified by PCR using human umbilical vein endothelial cell genomic DNA and inserted into the KpnI sites of pGL2-basic (Promega, Madison, USA).

\section{DCFH-DA assay}

For determination of total ROS generation, the hindgut of wild type and cad heterozygous adult flies were homogenized in homogenizing buffer $\left(50 \mathrm{mM} \mathrm{K}^{+}\right.$phosphate buffer, $\mathrm{pH}$ 7.4) and centrifuged at $12,000 \mathrm{rpm}$ at $4^{\circ} \mathrm{C}$ for 10 min. 25 mM DCFH-DA (2', 7'-dichlorofluoroscein diacetate) was added to the extracts and changes in fluorescence intensity were measured on a Fluorescence Microplate Reader (FL500, Bio-Tek Instruments, Winooski, USA) with excitation wavelength of $486 \mathrm{~nm}$ and emission wavelength of $530 \mathrm{~nm}$ for $1 \mathrm{hr}$. The fluorescence intensities were normalized to protein amounts determined by the BCA protein kit (Sigma, St. Louis, MO).

\section{Cell culture}

Drosophila Kc cells were grown at $25^{\circ} \mathrm{C}$ in M3 (BF) medium (Sigma) supplement with 1\% fetal bovine serum (FBS), 100 units $/ \mathrm{ml}$ of penicillin and $100 \mathrm{\mu g} / \mathrm{ml}$ of streptomycin (Gibco BRL, Gaithersburg, MD). Human colorectal carcinoma cell lines, DLD1, HCT116, SW480 and SW620 were cultured in RPMI 1640 Medium (Gibco/BRL), supplemented with $10 \% \mathrm{FBS}, 100$ units $/ \mathrm{ml}$ of penicillin and $100 \mu \mathrm{g} / \mathrm{ml}$ of streptomycin at $37^{\circ} \mathrm{C}$ incubator containing $5 \% \mathrm{CO}_{2}$. HCT-pcDNA3, HCT-CDX1, and HCT-CDX2 cell lines were obtained by stable transfecting the pcDNA3.0, pcDNA3/ CDX1 [25], and pcDNA3/CDX2 [25] plasmids into HCT116 cells; and stable clones were isolated after 2-3 weeks of G418 $(700 \mu \mathrm{g} / \mathrm{ml})$ selection.

\section{DNA transfection and luciferase assay}

Transfection of DNA mixtures into Drosophila Kc cells was performed using DDAB (Dimethyldioctadecyl ammonium bromide) [13] and the cells were harvested at $48 \mathrm{hr}$ after transfection. Lipofectamine Reagent (Gibco/BRL)mediated transfection into HCT-pcDNA3, HCT-CDX1, and HCT-CDX2 cell lines was performed using 24-well tissue culture plates according to the supplier's protocol. The luciferase assay was carried out by means of a Luciferase Assay System (Promega), as described previously [16]. Normalized luciferase activities were calculated by determining the luciferase/ $\beta$-galactosidase activity ratios, and reported as the 
mean \pm S.D. from triplicate transfections.

\section{RT-PCR}

Total RNA from larvae was isolated with Trizol Reagent and CDNAs were synthesized with M-MLV-RT. The RT-PCR products were analyzed on agarose gels stained with ethidium bromide. Oligonucleotide primers for PCR were designed as follows.

caudal, $5^{\prime}$ CGAGCAACAAGAAGGGTAGC $3^{\prime}$ and $5^{\prime}$ TGATGGGGCTCCATGTAGTT $3{ }^{\prime}$

catalase, 5' GGTACCCT TTGAGGTGACCCACGACA 3' and 5' TACGAGCAGGCC AAGAAGTTGGTACC 3'

ribosomal protein 49 (rp49), 5' GACAACAGAGYCGG TCGC $3^{\prime}$ and $5^{\prime}$ GTTGTGCACCAGGAACTT $3^{\prime}$

$C D X 1,5^{\prime}$ TGTGGCAGCGGTAAGACCCGAACC $3^{\prime}$ and

5' GGACTTGCGCCGGATAGT TGAGTA 3'

$C D \times 2, \quad 5^{\prime}$ CGGCTGGAGCTGGAGAAGG $3^{\prime}$ and $5^{\prime}$ TCAGCCTGGAATTGCTCTGC 3'

$\beta$-actin, 5' GACTACCTCATGAAGATC $3^{\prime}$ and $5^{\prime}$ GATCCACATCTGCTGGAA $3^{\prime}$

\section{Immunoblotting}

A preparation of cell extracts and immunoblotting were performed as described earlier [12]. Immunoblotting was performed using specific antibody for CDX1, Catalase (Santa-Cruz, Santa cruz, CA), $\alpha$-tubulin antibody (Goma Biotech) and HRP-conjugated anti-mouse antibody (Santa Cruz). CDX1 and CDX2 antibody were kindly supplied by Dr W.J. Lee. Proteins were visualized with enhanced chemiluminescence (ECL) detection system (Amersham, Piscataway, NJ).

\section{Results and Discussion}

We established previously catalase-lac $Z$ reporter transgenic flies for Drosophila catalase gene expression [29]. The catalase-lac $Z$ expression is detected in the hindgut of adults, Drosophila homolog of colon [29]. Therefore, to investigate the role of Caudal in catalase expression, we examined whether the expression of catalase-lac $Z$ is modulated by a Caudal mutant cad, which was generated by $\gamma$-ray-induced mitotic recombination [5]. The catalase-lac $Z$ expression was significantly reduced in the hindgut of cad heterozygous adult flies compared to that of wild type (Fig. 1A). We also examined quantitative $\beta$-galactosidase activities in the hindgut of these flies. The $\beta$-galactosidase activity in cad

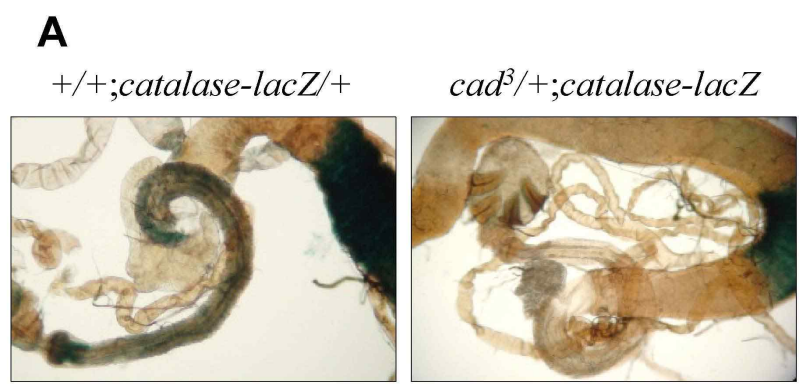

B

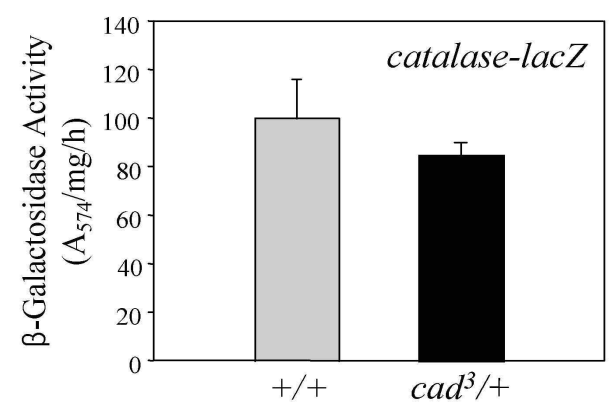

C

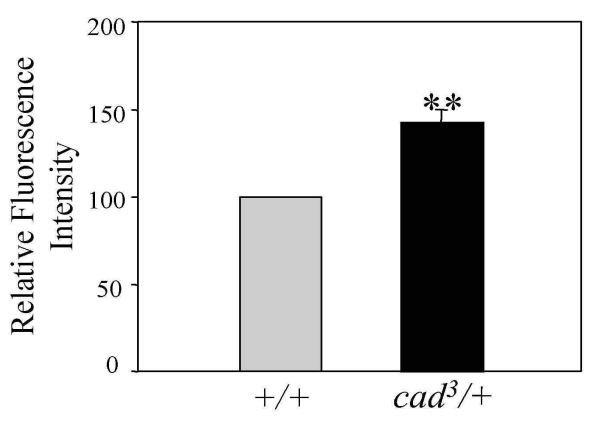

Fig. 1. A decreased expression of catalase gene and increased ROS generation in the hindgut of Caudal mutant heterozygous $\left(\mathrm{cad}^{3} / \mathrm{A}\right)$ adult flies. (A) Expression of catalase-lac $Z$ in the hindgut of wild type and cad heterozygous adult flies. The adult tissues were dissected and stained with $0.2 \% \mathrm{X}$-gal solution in the dark. Expression of $\beta$-galactosidase in the hindgut was decreased by $\mathrm{cad}^{3}$ allele. (B) Quantitative $\beta$-galactosidase activities of the hindgut of wild type and cad heterozygous adult flies. The adult hindgut extracts were prepared from 3-day-old adult transgenic flies as described in Materials and Methods. The $\beta$-galactosidase activities are expressed as absorbance unites at $574 \mathrm{~nm} / \mathrm{mg}$ of protein. Averaged values obtained from four independent experiments with \pm S.E. values are shown. (C) Comparison of ROS generation in the hindgut of wild type and cad heterozygous adult flies. The generation of ROS was measured by DCFH-DA assay. Changes of fluorescence intensity were measured with excitation and emission wavelength of $486 \mathrm{~nm}$ and 530 $\mathrm{nm}$, respectively for $1 \mathrm{hr}$. Fluorescence intensities are shown as relative intensity compared to wild type. Each value is the mean \pm S.E. from four independent experiments. A statistical significance is marked as ${ }^{* *} p<$ 0.01 . 
heterozygous adult hindgut was reduced to $83-85 \%$ of wild type, as shown in Fig. 1B. It has been well known that the catalase gene expression is critical for ROS homeostasis [32]. Therefore, we measured ROS generation in the hindgut of wild type and cad heterozygous adults. ROS generation in the hindgut of cad heterozygous adults was significantly higher than that of wild type (Fig. 1C). To further understand the role of Caudal on catalase gene expression, we examined whether Caudal overexpression stimulates catalase gene expression. The effect of Caudal on catalase promoter activity was examined by transient transfection experiment in the Drosophila Kc cell line using the catalase reporter plasmid pcatalase-Luc and Caudal expression plasmid pAct-cad The catalase promoter activity was dose-dependently transactivated by Caudal (Fig. 2A). To investigate the upregulation of catalase expression by Caudal in living flies, Caudal overexpression in living flies was performed with the GAL4-UAS system [11]. Transgenic flies carrying UAS-Cad were crossed with transgenic flies carrying GAL4 cDNA placed under control of the hsp70 gene promoter (hs-GALA). Caudal overexpression in third instar larvae carrying single copies of both hs-GALA and UAS-Cad was confirmed by RT-PCR (Fig. 2B). The level of catalase mRNA was increased by heat shock-induced Caudal (Fig. 2B). Thus, these results indicate that Caudal regulates positively catalase gene expression at transcriptional level.

Since we found several sequences similar to the Caudal-related homeodomain binding consensus sequences in the 5'-flanking region of human Catalase gene, to investigate whether human Catalase gene expression is regulated by CDX1 and CDX2, human homologs of caudal, the reporter plasmid phCat-Luc was constructed (Fig. 3A). Effects of CDX1 and CDX2 on Catalase gene promoter activity were examined by transient transfection experiments with phCat-Luc reporter plasmid and $\mathrm{p} C D N A 3 / C D X 1$ or pcDNA3 $C D X 2$ expression plasmid in colorectal carcinoma cell line HCT116. Human Catalase promoter activity was transactivated dose-dependently by CDX1 and CDX2 expression plasmids, up to nearly 7- and 4-fold, respectively (Fig. 3B). We established CDX1 and CDX2 stable transfectant clones in HCT116 cell line (HCT-CDX1 and HCT-CDX2). The overexpression of CDX1 and CDX2 in these stable transfectants was confirmed by RT-PCR, respectively (Fig. 4A). To confirm whether Catalase promoter activity is regulated by CDX1 and CDX2, phCat-Luc was transfected into CDX1 and CDX2 stable transfectants,
A

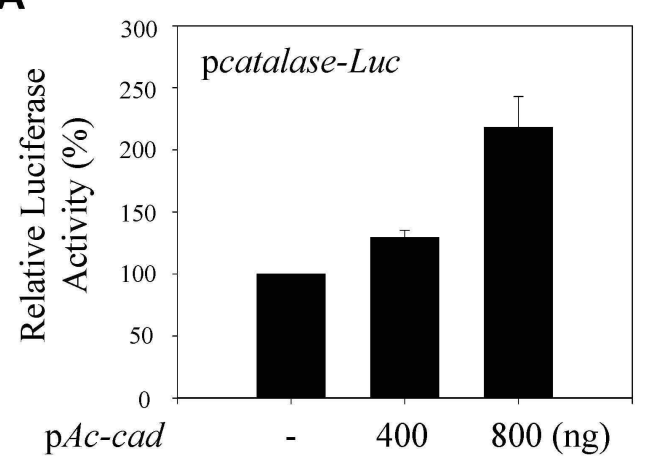

B

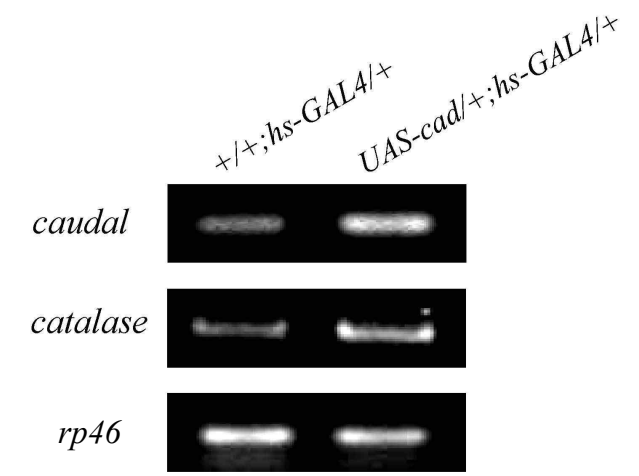

Fig. 2. Caudal over-expression induces catalase gene expression. (A) Luciferase reporter assay shows a strong and dose-dependent stimulation of the catalase reporter by Caudal. Each transfection mixture consisted of the pcatalase-Luc reporter plasmid and pactin-Lac $Z$ internal control plasmid. The 400 or $800 \mathrm{ng}$ of $\mathrm{p} A c$-cad or the plasmid $\mathrm{p} A c$ for the control (mock) of effector was cotransfected in Drosophila Kc cells. Normalized luciferase activities were calculated by determining the luciferase/ $\beta$-galactosidase activity ratios. (B) Total RNA was prepared from the third instar larvae incubated at $25^{\circ} \mathrm{C}$ for $24 \mathrm{hr}$ after heat shock at $37^{\circ} \mathrm{C}$ for $45 \mathrm{~min}$. Caudal over-expression was confirmed by RT-PCR. Level of Drosophila catalase mRNA was examined by RT-PCR using specific primers. control, $+4, h s-G A L 4 /$. Caudal, $U A S-c a d / 4, h s-G A L 4 / 4$.

respectively. The luciferase activities in the HCT-CDX1 and in the HCT-CDX2 cell lines were 9- to 11-fold and 4-fold of the HCT-pcDNA3, respectively (Fig. 4B). To confirm the stimulatory effects of CDX1 and CDX2 on Catalase promoter activity, we examined levels of Catalase protein in HCT-CDX1and HCT-CDX2 stable transfectants by Western blot. The protein levels of Catalase in HCT-CDX1 and HCT-CDX2 were higher than that in HCT-pcDNA3 (Fig. 4C). These results indicate that human Catalase is up-regulated by Caudal-related homeodomain proteins CDX1 and CDX2 and that transactivating activity of CDX1 on Catalase promoter activity is higher than that of CDX2. 
A

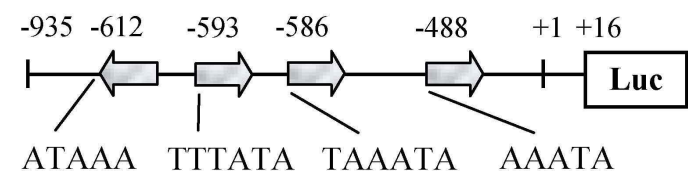

B

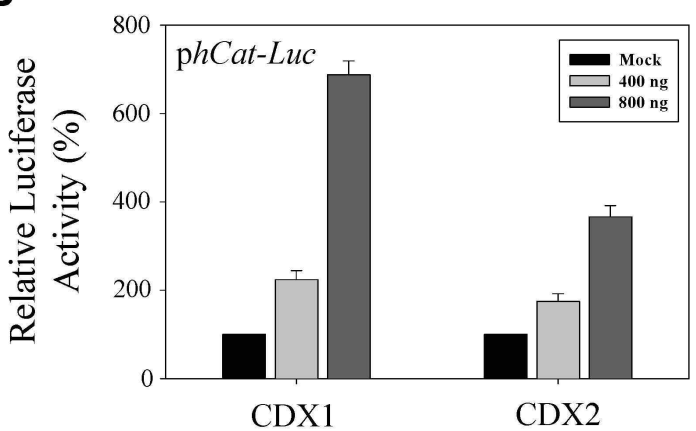

Fig. 3. CDX1 and CDX2 increase Catalase promoter activity in colorectal carcinoma cell line HCT116. (A) The potential Caudal-related homeodomain protein binding sites in human Catalase gene promoter are shown. The transcription initiation site is numbered +1 . (B) Luciferase reporter assay shows dose-dependently stimulation of the Catalase reporter by CDX1 and CDX2. Transfection mixture was consisted of the phCat-Luc reporter plasmid and SV40-LacZ internal control plasmid. The 400 or $800 \mathrm{ng}$ of $\mathrm{p} C D N A 3 / C D X 1$ or $\mathrm{p} C D N A 3 / C D X 2$ plasmid and pCDNA3.0 plasmid for the control of effector were cotransfected in colorectal carcinoma cell line HCT116. Normalized luciferase activities were calculated by determining the luciferase/ $\beta$-galactosidase activity ratios.
To further confirm the effect of CDX1 on Catalase expression, levels of Catalase in four colorectal carcinoma cell lines (DLD1, HCT116, SW480 and SW620) were examined by Western blot. Recently, it was reported that CDX1 mRNA is expressed in SW480 and SW620 cell lines, but not in DLD1 and HCT116 cell lines [32]. We examined the protein expression of CDX1 in these cell lines. CDX1 expression was detected in SW480 and SW620 cell lines, but not in DLD1 and HCT116 cell lines. This result is consistent with the previous report. The protein levels of Catalase in SW480 and SW620 cell lines expressing CDX1 were higher than those in DLD1 and HCT116 (Fig. 5). This result indicates that the level of Catalase in four colorectal carcinoma cell lines is correlated with or without CDX1 expression, supporting the transactivating activity of CDX1 on Catalase promoter activity.

In the present study, we have shown that the Caudal-related homeodomain proteins positively regulate catalase expression in both Drosophila hindgut and human colorectal carcinoma cells. The expression of CDX1 and/or CDX2 is decreased in the majority of the colon carcinomas $[3,40]$, although the expression of CDX1 is controversial during colorectal cancer progression [10]. Oxidative stress can induce DNA damages that lead to genomic instability and possibly stimulate cancer progression [16]. Elevated Reactive oxygen species (ROS) levels and oxidative stress are responsible for constant activation of transcription factors, such as NF $\kappa \mathrm{B}$ and AP-1, during tumor progression
A

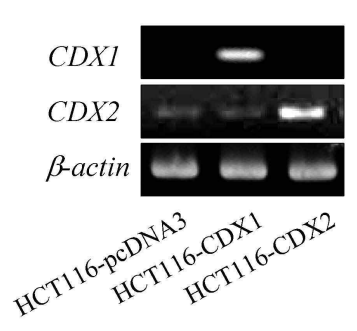

B

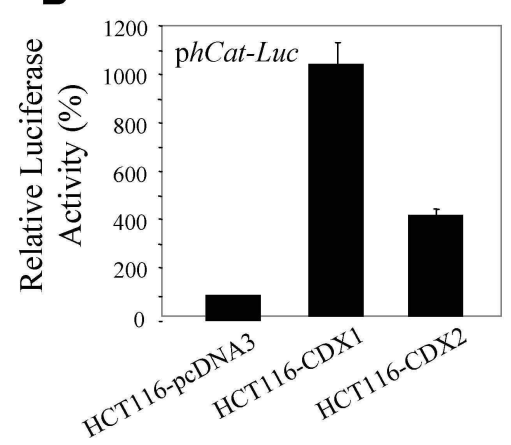

C

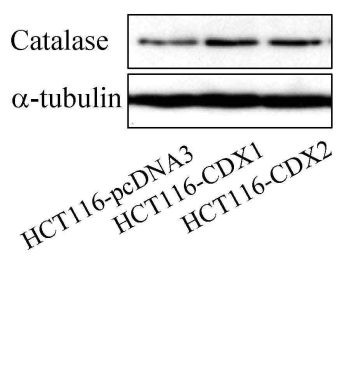

Fig. 4. Catalase promoter activities and protein levels in HCT-CDX1 and HCT-CDX2 stable transformants. (A) Total RNA was isolated from HCT-pcDNA3, HCT-CDX1, and HCT-CDX2 stable HCT116 cell lines. mRNA expression was monitored by RT-PCR. $\beta$-Actin was used as a positive control. (B) Catalase promoter activities are increased in HCT-CDX1 and HCT-CDX2 stable transformants. Transfection mixture was consisted of the phCat-Luc reporter plasmid and SV40-LacZ internal control plasmid. The mixture was transfected into HCT-pcDNA3, HCT-CDX1 and HCT-CDX2 stable HCT116 cell lines. Normalized luciferase activities were calculated by determining the luciferase/ $\beta$-galactosidase activity ratios. (C) Catalase protein levels are increased in HCT-CDX1 and HCT-CDX2 stable transformant. Protein extracts $(50 \mu \mathrm{g})$ of the HCT-pcDNA3, HCT-CDX1 and HCT-CDX2 cell lines were fractionated on a 10\% SDS-PAGE and analyzed by Western blotting using the specific antibodies as noted. $\alpha$-tubulin was served as a loading control. 


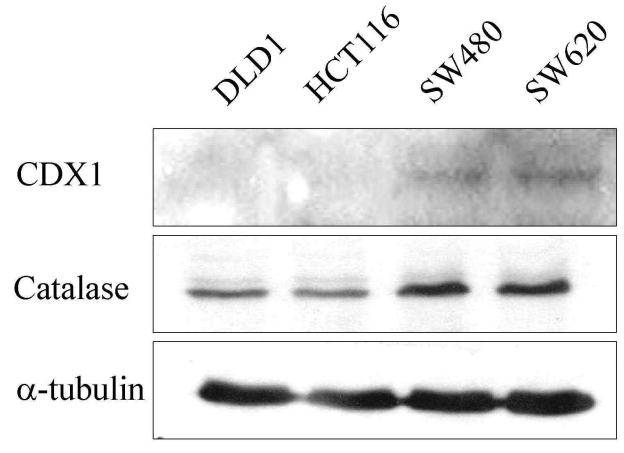

Fig. 5. The protein levels of human Catalase in different colorectal cancer cell lines. Protein extracts $(50 \mu \mathrm{g})$ isolated from DLD1, HCT116, SW480 and SW620 cells were separated on 10\% SDS-PAGE and Western blot analysis was performed with the specific antibodies as noted. $\alpha$ -tubulin was served as a loading control.

[12]. Thus, ROS and oxidative stress are thought to play multiple roles in tumor initiation, progrssion and maintenance. Colorectal carcinogenesis has been well known to be associated with serious oxidative stress [4]. Evidences have been given in some reports that $\mathrm{H}_{2} \mathrm{O}_{2}$ could promote cell growth and related gene expression in human tumors such as breast cancer and colon cancer [17,31,42]. From these facts, our results suggest that loss or reduction of CDX1 and/or CDX2 causes decreased expression of Catalase, which may increase oxidative stress in colon, accumulate genetic alterations and induce tumorigenesis.

Numerous studies also demonstrate evidences that oxidative stress occurs the pathogenesis of endotoxin-induced motility disturbances in animals and humans, and that oxygen-derived free radicals are implicated as relevant mediators in sepsis and septic shock $[1,9,39]$. Oxidative stress participates in the upregulation of iNOS expression, COX2 expression and NF- $\mathrm{B}$ activity, which are inhibited by Catalase [37,39]. Thus, down-regulation of Catalase expression due to loss or reduction of CDX1 and/or CDX2 may attenuate the endotoxin-related defense system, which may induce intestinal diseases such as intestinal ischemia and chronic inflammatory bowel disease as well as cancer.

Ectopic expression of CDX1 and CDX2 in adenomas of the stomach, esophagus, and liver has been reported $[2,30,38]$. Overexpression of CDX1 in colon cancer was also reported [10]. Since many anticancer drugs have been suggested to cause oxidative stress [22,35] and Catalase activity is associated with the acquisition of cellular resistance to anticancer drugs [14,19], increased Catalase in cancer cells overexpressing CDX1 and CDX2 may also convey resistance to anticancer drugs.

In summary, our results indicate that upregulation of catalase gene by Caudal-related homeodomain proteins is conserved evolutionarily from flies to human and suggest the possibility that Caudal-related homeodomain proteins CDX1 and CDX2 are involved in intestinal homeostasis and tumorigenesis via up-regulation of catalase expression.

\section{Acknowledgement}

We would like to thank Dr. WJ Lee for CDX1/2 expression plasmids. We thank the Bloomington Drosophila Stock Center for fly stocks. This work was supported for two years by Pusan National University Research Grant.

\section{References}

1. Albuszies, G. and U. B. Bruckner. 2003. Antioxidant therapy in sepsis. Intensive Care Med 29, 1632-1636.

2. Almeida, R., E. Silva, F. Santos-Silva, D. G. Silberg, J. Wang, C. De Bolos, and L. David. 2003. Expression of intestine-specific transcription factors, CDX1 and CDX2, in intestinal metaplasia and gastric carcinomas. J. Pathol. 199, 36-40.

3. Baba Y., K. Nosho, K. Shima, E. Freed, N. Irahara, J. Philips, J. A. Meyerhardt, J. L. Hornick, R. A. Shivdasani, C. S. Fuchs, and S. Ogino. 2009. Relationship of CDX2 loss with molecular features and prognosis in colorectal cancer. Clin. Cancer Res. 15, 4665-4673.

4. Bartsch, H., J. Nair, and R. W. Owen. 2002. Exocyclic DNA adducts as oxidative stress markers in colon carcinogenesis: potential role of lipid peroxidation, dietary fat and antioxidants. Biol. Chem 383, 915-921.

5. Butler, H., S. Levine, X. Wang, S. Bonyadi, G. Fu, P. Lasko, B. Suter, and R. Doerig. 2001. Map position and expression of the genes in the 38 region of Drosophila. Genetics 158, 1597-1614.

6. Chawengsaksophak, K., R. James, V. E. Hammond, F. Kontgen, and F. Beck. 1997. Homeosis and intestinal tumours in Cdx2 mutant mice. Nature 386, 84-87.

7. Choi, Y. J., T. Y. Choi, M. Yamaguchi, A. Matsukage, Y. S. Kim, and M. A. Yoo. 2004. Transcriptional regulation of the Drosophila caudal homeobox gene by DRE/DREF. Nucleic Acids Res. 32, 3734-3742.

8. Crissey, M. A., R. J. Guo, S. Funakoshi, J. Kong, J. Liu, and J. P. Lynch. 2010. Cdx2 levels modulate intestinal epithelium maturity and Paneth cell development. Gastroenterology 140, 517-528.

9. Cuzzocrea, S., D. P. Riley, A. P. Caputi, and D. Salvemini. 2001. Antioxidant therapy: a new pharmacological approach in shock, inflammation, and ischemia/reperfusion 
injury. Pharmacol. Rev. 53, 135-159.

10. Domon-Dell, C., A. Schneider, V. Moucadel, E. Guerin, D. Guenot, S. Aguillon, I. Duluc, E. Martin, J. Iovanna, J. F. Launay, B. Duclos, M. P. Chenard, C. Meyer, P. Oudet, M. Kedinger, M. P. Gaub, and J. N. Freund. 2003. Cdx1 homeobox gene during human colon cancer progression. Oncogene 22, 7913-7921.

11. Fischer, J. A., E. Giniger, T. Maniatis, and M. Ptashne. 1988. GAL4 activates transcription in Drosophila. Nature 332, 853-856.

12. Gupta, A., S. F. Rosenberger, and G. T. Bowden. 1999. Increased ROS levels contribute to elevated transcription factor and MAP kinase activities in malignantly progressed mouse keratinocyte cell lines. Carcinogenesis 20, 2063-2073.

13. Han, K. 1996. An efficient DDAB-mediated transfection of Drosophila S2 cells. Nucleic Acids Res. 24, 4362-4363.

14. Hunt, C. R., J. E. Sim, S. J. Sullivan, T. Featherstone, W. Golden, C. Von Kapp-Herr, R. A. Hock, R. A. Gomez, A. J. Parsian, and D. R. Spitz. 1998. Genomic instability and catalase gene amplification induced by chronic exposure to oxidative stress. Cancer Res. 58, 3986-3992.

15. Hwang, M. S., Y. S. Kim, N. H. Choi, J. H. Park, E. J. Oh, E. J Kwon, M. Yamaguchi, and M. A. Yoo. 2002. The caudal homeodomain protein activates Drosophila E2F gene expression. Nucleic Acids Res. 30, 5029-5035.

16. Jackson, A. L. and L. A. Loeb. 2001. The contribution of endogenous sources of DNA damage to the multiple mutations in cancer. Mutat. Res. 477, 7-21.

17. Joseph, P., T. K. Muchnok, M. L. Klishis, J. R. Roberts, J. M. Antonini, W. Z. Whong, and T. Ong. 2001. Cadmium-induced cell transformation and tumorigenesis are associated with transcriptional activation of c-fos, c-jun, and c-myc proto-oncogenes: role of cellular calcium and reactive oxygen species. Toxicol. Sci. 61, 295-303.

18. Kessel, M. and P. Gruss. 1990. Murine developmental control genes. Science 249, 374-379.

19. Kim, H. S., T. B. Lee, and C. H. Choi. 2001. Down-regulation of catalase gene expression in the doxorubicin-resistant AML subline AML-2/DX100. Biochem Biophys. Res. Commun. 281, 109-114.

20. Kuhnlein, R. P., G. Bronner, H. Taubert, and R. Schuh. 1997. Regulation of Drosophila spalt gene expression. Mech Dev. 66, 107-118.

21. Lauer, C., A. Volkl, S. Riedl, H. D. Fahimi, and K. Beier. 1999. Impairment of peroxisomal biogenesis in human colon carcinoma. Carcinogenesis 20, 985-989.

22. Lewis, A. D., I. D. Hickson, C. N. Robson, A. L. Harris, J. D. Hayes, S. A. Griffiths, M. M. Manson, A. E. Hall, J. E. Moss, and C. R. Wolf. 1988. Amplification and increased expression of alpha class glutathione S-transferase-encoding genes associated with resistance to nitrogen mustards. Proc. Natl. Acad Sci. USA 85, 8511- 8515.

23. Lewis, M. T. 2000. Homeobox genes in mammary gland development and neoplasia. Breast Cancer Res. 2, 158-169.

24. Luo, D. and T. A. Rando. 2003. The regulation of catalase gene expression in mouse muscle cells is dependent on the
CCAAT-binding factor NF-Y. Biochem Biophys. Res. Commun. 303, 609-618.

25. Mallo, G. V., H. Rechreche, J. M. Frigerio, D. Rocha, A. Zweibaum, M. Lacasa, B. R. Jordan, N. J. Dusetti, J. C. Dagorn, and J. L. Iovanna. 1997. Molecular cloning, sequencing and expression of the mRNA encoding human $\mathrm{Cdx} 1$ and $\mathrm{Cdx} 2$ homeobox. Down-regulation of $\mathrm{Cdx} 1$ and $\mathrm{Cdx} 2$ mRNA expression during colorectal carcinogenesis. Int. J. Cancer 74, 35-44.

26. McGinnis, W. and R. Krumlauf. 1992. Homeobox genes and axial patterning. Cell 68, 283-302.

27. Michiels, C., M. Raes, O. Toussaint, and J. Remacle. 1994. Importance of Se-glutathione peroxidase, catalase, and $\mathrm{Cu} / \mathrm{Zn}-\mathrm{SOD}$ for cell survival against oxidative stress. Free Radic. Biol. Med 17, 235-248.

28. Nenoi, M., S. Ichimura, K. Mita, O. Yukawa, and I. L. Cartwright. 2001. Regulation of the catalase gene promoter by Sp1, CCAAT-recognizing factors, and a WT1/Egr-related factor in hydrogen peroxide-resistant HP100 cells. Cancer Res. 61, 5885-5894.

29. Park, S. Y., Y.S. Kim, D. J. Yang, and M. A. Yoo. 2004. Transcriptional regulation of the Drosophila catalase gene by the DRE/DREF system. Nucleic Acids Res. 32, 1318-1324.

30. Ren, P., D. G. Silberg, and A. E. Sirica. 2000. Expression of an intestine-specific transcription factor (CDX1) in intestinal metaplasia and in subsequently developed intestinal type of cholangiocarcinoma in rat liver. $A m \mathrm{~J}$. Pathol. 156, 621-627.

31. Rhee, S. G. 1999. Redox signaling: hydrogen peroxide as intracellular messenger. Exper. Mol. Med 35, 53-59.

32. Sanders, L. M., C. E. Henderson, M. Y. Hong, R. Barhoumi, R. C. Burghardt, N. Wang, C. M. Spinka, R. J. Carroll, N. D. Turner, R. S. Chapkin, and J. R. Lupton. 2004. An increase in reactive oxygen species by dietary fish oil coupled with the attenuation of antioxidant defenses by dietary pectin enhances rat colonocyte apoptosis. J. Nutr. 134, 3233-3238.

33. Silberg, D. G., G. P. Swain, E. R. Suh, and P. G. Traber. 2000. $\mathrm{Cdx} 1$ and $\mathrm{Cdx} 2$ expression during intestinal development. Gastroenterology 119, 961-971.

34. Skrzydlewska, E., S. Sulkowski, M. Koda, B. Zalewski, L. Kanczuga-Koda, and M. Sulkowska. 2005. Lipid peroxidation and antioxidant status in colorectal cancer. World J. Gastroenterol. 11, 403-406.

35. Tsutsumishita, Y., T. Onda, K. Okada, M. Takeda, H. Endou, S. Futaki, and M. Niwa. 1998. Involvement of $\mathrm{H}_{2} \mathrm{O}_{2}$ production in cisplatin-induced nephrotoxicity. Biochem Biophys. Res. Commun. 242, 310-312.

36. Van Remmen, H., M. D. Williams, H. Yang, C. A. Walter, and A. Richardson. 1998. Analysis of the transcriptional activity of the $5^{\prime}$-flanking region of the rat catalase gene in transiently transfected cells and in transgenic mice. J. Cell Physiol. 174, 18-26.

37. Wang, W. W., D. L. Smith, and S. D. Zucker. 2004. Bilirubin inhibits iNOS expression and NO production in response to endotoxin in rats. Hepatology 40, 424-433. 
38. Werling, R. W., H. Yaziji, C. E. Bacchi, and A. M. Gown. 2003. CDX2, a highly sensitive and specific marker of adenocarcinomas of intestinal origin: an immunohistochemical survey of 476 primary and metastatic carcinomas. Am J. Surg. Pathol. 27, 303-310.

39. de Winter, B. Y., L. van Nassauw, J. G. de Man, F. de Jonge, A. J. Bredenoord, T. C. Seerden, A. G. Herman, J. P. Timmermans, and P. A. Pelckmans. 2005. Role of oxidative stress in the pathogenesis of septic ileus in mice. Neurogastroenterol. Motil. 17, 251-261.

40. Wong, N. A., M. P. Britton, G. S. Choi, T. K. Stanton, D. C. Bicknell, J. L. Wilding, and W. F. Bodmer. 2004. Loss of CDX1 expression in colorectal carcinoma: promoter methylation, mutation, and loss of heterozygosity analyses of 37 cell lines. Proc. Natl. Acad Sci. USA 101, 574-579.

41. Wu, L. H. and J. A. Lengyel. 1998. Role of caudal in hindgut specification and gastrulation suggests homology between Drosophila amnioproctodeal invagination and vertebrate blastopore. Development 125, 2433-2442.

42. Zhu, J. W., B. M. Yu, Y. B. Ji, M H. Zheng, and D. H. Li. 2002. Upregulation of vascular endothelial growth factor by hydrogen peroxide in human colon cancer. World J. Gastroenterol. 8, 153-157.

초록 : 초파리 대장조직과 인간 대장암세포주에서의 caudal 단백질에 의한 catalase 발현 조절

박재홍 $^{1+} \cdot$ 박소영 $^{1 \dagger} \cdot$ 이동호 $\cdot$ 김영신 ${ }^{2} \cdot$ 유미애 ${ }^{1}$

(부산대학교, ${ }^{1}$ 분자생물학과, ${ }^{2}$ 유전공학연구소)

Caudal homeodomain 단백질은 초파리에서 사람에 이르기까지 보존되어 있으며, 장조직의 발생과 유지에 필 수적인 역할을 한다. $\mathrm{CDX} 1$ 과 $\mathrm{CDX} 2$ 의 발현 감소 혹은 소실이 대장암과 연관되어 있음이 잘 알려져 있다. 대장암 발생은 산화성 스트레스와 밀접한 관련이 있으며, 대장암 조직에서 항산화효소인 catalase의 발현이 감소되어 있 다. 하지만 그 분자적 기전은 잘 밝혀져 있지 않다. 본 연구에서는 초파리와 사람의 caudal homeodomain 단백질 들이 catalase의 발현을 조절하는 것을 보여준다. 초파리 caudal heterozygous 돌연변이체의 대장조직에서 catalase의 발현이 감소되어 있고 ROS 생성이 증가되어 있음을 관찰하였다. 그리고 caudal 유전자의 과발현에 의해 catalase promoter의 활성과 mRNA 수준이 각각 증가함을 확인하였다. 또한 사람의 대장암 세포주인 HCT116 세포에서 $\mathrm{CDX} 1$ 과 $\mathrm{CDX} 2$ 가 catalase promoter의 활성과 단백질 수준에서 catalase를 상향 조절함을 관찰하였다. 이러한 결과들은 $\mathrm{CDX} 1$ 과 $\mathrm{CDX} 2$ 가 catalase 발현 조절을 통하여 장의 항상성 유지와 암발생 과정에 관여함을 시 사한다. 